Portland State University

PDXScholar

Engineering and Technology Management

Faculty Publications and Presentations

\title{
Managing Technology in Financial Innovation
}

Frederick Betz

Portland State University

Follow this and additional works at: https://pdxscholar.library.pdx.edu/etm_fac

Part of the Engineering Commons, and the Technology and Innovation Commons

Let us know how access to this document benefits you.

\section{Citation Details}

F. Betz, "Managing technology in financial innovation," 2016 Portland International Conference on Management of Engineering and Technology (PICMET), Honolulu, HI, 2016.

This Article is brought to you for free and open access. It has been accepted for inclusion in Engineering and Technology Management Faculty Publications and Presentations by an authorized administrator of PDXScholar. Please contact us if we can make this document more accessible: pdxscholar@pdx.edu. 


\title{
Managing Technology in Financial Innovation
}

\author{
Frederick Betz \\ Dept. of Engineering and Technology Management, Portland State University, Portland, OR - USA
}

\begin{abstract}
The topic of managing technology had traditionally focused upon the manufacturing industries; but the service industries grew to become a major sector of industry and commerce. We examine how to manage technology in the financial commercial sector. What is innovation in the financial sector? How does innovation occur in the financial sector? What are the criteria of technology safety in financial innovations? Why did financial innovation contribute to financial instabilities, such as the Global Financial Crisis of 2007-08? Why had governmental agencies failed to properly regulate the financial sector for safety? How did U.S. government financial agencies handle that financial crisis to result in a major recession rather than a second Great Depression? This paper is a cross-disciplinary study between MOT and economics.
\end{abstract}

\section{INTRODUCTION}

In the last half of the twentieth century, Information and Communications (IC) technologies had been implemented to program and speed financial transactions; but the innovation of IC technologies was not, in itself, a financial innovation. Similar to the innovation of computers into manufacturing processes, it was about how computers were used to improve manufacturing, such in as computer-aided-design (CAD) or computer-aided-manufacturing $\quad(\mathrm{CAM}) . \quad$ Financial innovations are also about how computers and the communications are used in financial services. We review the recent history of financial innovation in financial products, which include: junk bonds, sub-prime mortgages, securitized derivatives, and credit default swaps.

There are many other innovations, but these tend to be operational. The performance of the financial system depends upon financial 'products'. These are the transactions occurring through the operations. It is like in manufacturing, manufactured products are produced by operations but products are sold in the market. The performance of the commodity market or financial market depends upon the supply and demand of products and upon the quality and price of the products.

We will focus upon financial safety and stability. Did the IC technology somehow encourage the failure of international financial institutions in performing with basic financial 'integrity', 'honesty', and 'prudence'? How did IC technology assist the financial system to operate more 'efficiently' but also more ineffectively? So 'ineffective' were the financial innovation of securitized derivatives and credit default swap innovations that they together brought down the world's financial system in 2007-08.

\section{METHODOLOGY}

Testing a social science theory for empirical validity (such as the macro-economic theory underlying 'austerity), one needs first to methodologically formulate a specific 'model' within the principles of the theory - in order to test in the empirical context of a historical event of a society the validity of the model. Models can be directly empirically verified or invalidated. Theory and theoretical principles of a theory are only indirectly validated/invalidated by implications of the validity of their models. We use a case study to verify a model. Contemporary cases are a blend of the case approach and historical methodology. In historical methodology, sources and direct quotes provide evidence of historical information and interpretation. Contemporary case studies derive historical information from investigative reporters on economic and financial events and on interpretation of these events by contemporary economists and economic commentators. The direct quotes in this article point to sources of historical evidence.

\section{BACKGROUND}

To answer issues of safety in financial innovations, we must observe the financial system within an IC network, as a kind of financial 'grid'. For this, we review the systems representation of the production of financial products and also review the modeling of 'financial transactions as a financial market.

\section{A. Banking Network}

Banks operate within a financial network. Financial markets are markets to trade capital assets packaged as 'financial products'; and such financial products are part of the financial services provided in a banking network -involving commercial banks, investment banks, and shadow banks. Investment banks and shadow banks borrow from commercial banks, for leverage in making investments. The commercial bank takes in deposits of savings, and the investment banks produce financial products to sell to commercial banks and investors (demand for investments).

An investment bank creates the financial intermediation process by formulating a financial product, which is based upon two economic values: (1) the estimated market value of the capital asset and (2) the interest rate (rent) of the financial product. This financial product is then available for sale in a financial market (e.g. corporate equity stocks in a stock market or derivatives in a derivative market or international currency exchanges in a currency exchange market). The economic value of the financial product is determined by its 
pricing in its financial market; and if a financial bubble occurs in the market (such as the housing bubble in 2005 in the mortgage derivative market), then the bubble can burst, dropping the market. Thus the financial product value depends upon: (1) its initial value when sold and (2) its later value when traded in a market.

The traditional function of investment banking has occurred in what has been called a 'financing life cycle' of business. Investment banking services involves finding investors to finance the start of a business, loaning money to the business to finance its growth, taking the business public by issuing stock, maintaining a trading market in the stock, and assisting the business to issue bonds for operations or acquisitions. Some investment banks (venture capital firms) specialize in financing the 'start-up' stage of a new business; while the traditional Wall Street investment banks specialize in the underwriting the public offering stage. In offering public stock, investment banks had to ensure the continuing market for stock by participating in a stock exchange (e.g. having a seat on the New York Stock Exchange). Traditional investment banks also sold corporate bond issues for further corporate financing.

It is the investment banks which formulate the financial products constituting a financial market; and Figure 1 depicts a systems representation of this process. [1]

In systems notation, the 'cloud' symbols are 'sources' as origins of things entering the 'flow' of the system -- things which flow along the 'arrow' lines of the system. The 'rectangle' symbols are stocks of things which receive, send, or hold the things flowing along the arrows. The 'circlewith-triangle' symbols are 'control valves' which control the 'rate-of-flow' of things along the arrows of the system. The 'system' model of an institutional process indicates a flow of things between sources and stocks in the system, controlled by valves along the flow lines.

The flow is 'capital' from a source of savers to a source of asset sellers, through the intermediary of the creation and trading of 'financial products' -products created by investment banks and traded in a financial market. As a financial intermediary, an investment bank brings together a financial supply side of capital assets to trade in a market with a financial demand side of buyers of the assets. For example, when an investment backs assists a private company in making a public offering of stock, the private company sells equity assets as stock and purchasers of the stock buy equity in the company.

Suzanne Mcgee wrote: "All of the players (on Wall Street) perform functions that link the 'buy side,' those who have capital and want to invest it profitably, and the 'sell side,' those entities in need of capital. 'At its heart, when it is doing what it does best, Wall Street is a superb gatekeeper, making matches between investors and businesses, governments, or anyone else who needs to finance something,' explains Mike Heffernan, a former Morgan Stanley banker." [2]

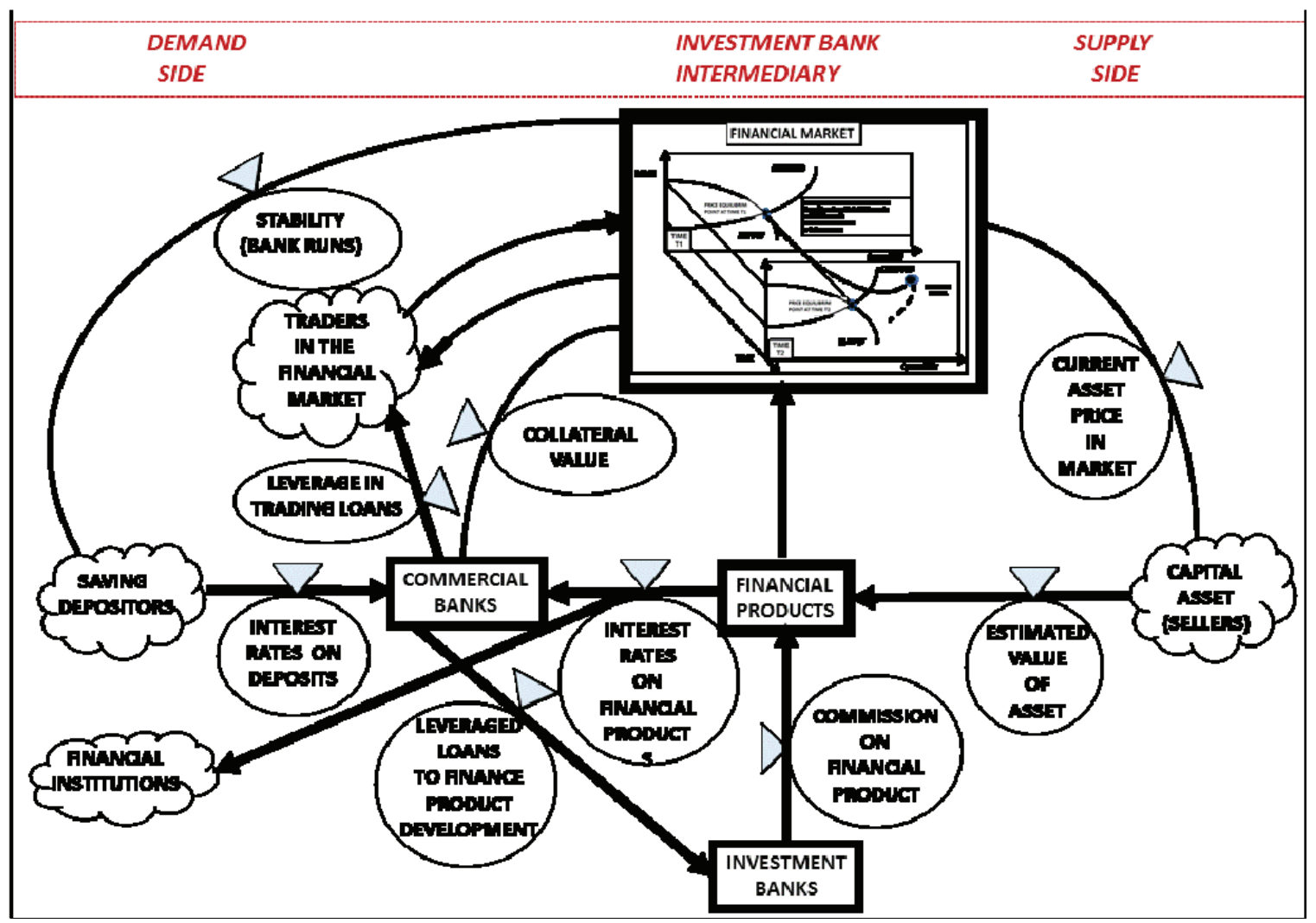

Figure 1. Disequilibrium Systems Model of Investment Bank Process 
The sellers and buyers of financial products have different interests, which the investment bank must bridge in creating a financial product. Suzanne Mcgee wrote: "The sell side wants to get as much capital on the most favorable terms possible from the buy side - investors who range in size and importance from individuals to mutual fund conglomerates such as Fidelity, and include hedge funds, private equity funds, foundations, college endowments, pension funds, venture capital partnerships, and ultra-wealthy individual investors such as Microsoft cofounder Paul Allen or financier George Soros. In a perfect world, the sell side would love free money - with no interest payable, no specific term for repayment, and no promises about increasing the value of the investment. It is the myriad institutions that collectively make up Wall Street that (in exchange for a fee) bring together the two parties and negotiate a compromise: the terms on which the buy side is willing to invest some of its capital and the sell side is willing to agree to in order to get its hands on that capital. Banks have been fulfilling that kind of function in more limited ways for centuries. ... Wall Street exists to help investors and those in need of capital find their way through the financing maze. Investment bankers still not only link the two sides but also help them sort out what terms are fair for the kind of capital being sought." [2]

The disequilibrium model of a financial market is composed of the financial products which trade capital assets; and the financial market may move toward a price disequilibrium, if and when the market becomes hot, as traders bid the price of the financial product higher into a financial bubble. As traders bid higher prices in the market, they need increasing larger leverage in the loans for purchase. When the leverage in the loans gets too high, then the market grows into a financial bubble and can collapse. In a financial market collapse, the financial products which the commercial banks have held as collateral can become valueless (toxic assets). The banks can become insolvent and collapse (bank runs).

\section{B. Financial Transactions}

Financial transactions involve the buying and selling of a 'capital asset'. Drawing upon the work of the economist, John Maynard Keynes, Minsky wrote: "In the General Theory, Keynes sought to create a model of the economy in which money is never neutral (to pricing). He did this by creating a model in which the price level of financial assets is determined in (financial) markets. Each capital and financial asset yields an income stream, (which) has carrying costs and possessing some degree of liquidity. The price level of assets is determined by the relative value (of) income and liquidity." [3]

For Keynes, a 'time-dependence of a financial transaction' was in the basic idea in a 'capital asset' having both a 'present-income' and a "future-liquidity'. A capital-asset is an investment which creates income and can later be sold, a present income-stream and also a future-liquidity. The time dimension is from (T1) of a present-income to (T2) of futureliquidity. This present- to-future (T1 to T2) temporal process occurs in a financial system as a transaction of "credit-debt". Minsky wrote: "Every capitalist economy is characterized by
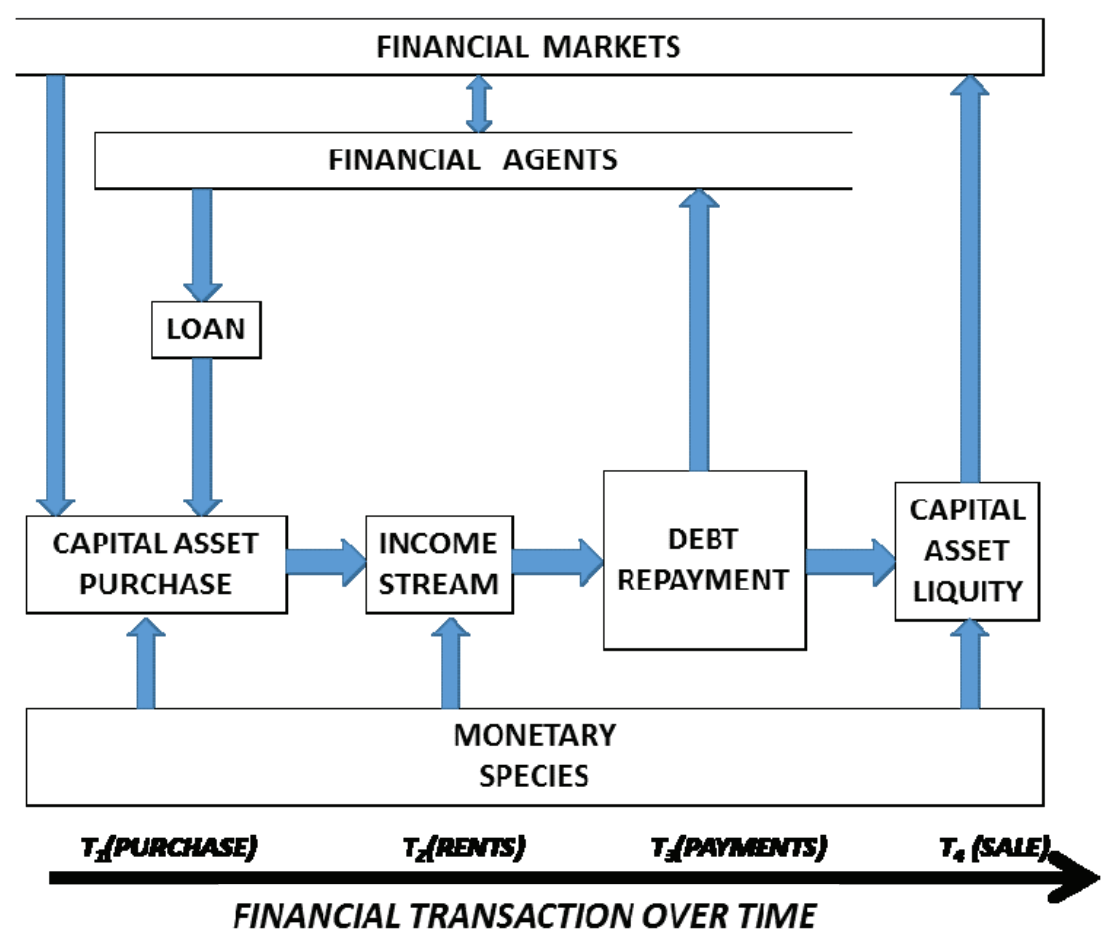

Figure 2. Keynes/Minsky Financial Process 
a system of borrowing and lending. The fundamental borrowing and lending act is an exchange of 'money-now' for 'money-in-the-future'. This exchange takes place in a negotiation in which the borrower demonstrates to the satisfaction of the lender-that the money of the future part of the contract will be forth-coming. The money in the future is to cover both the interest and the repayment of the principle of the contract." [3]

A financial market makes 'credit-debt contracts' sellable over time, as a 'future-liquidity'. Thus in a financial subsystem, three things are essential: 1) credit-debt transactions as a fundamental financial process; and 2) a capital-asset market for liquidity of the asset; and 3) money as a medium of value-exchange. As shown in Figure 2, the author [4] used Minsky's emphasis on a time dimension to model a financial market.

A financial capital-asset transaction occurs over time, beginning with a loan for an asset purchase, followed by rents (income stream) from the productivity of the capital asset, which are used for payments of the loan until the sale of the asset. Financial agents provide a purchase loan to the purchaser of the asset, receiving in turn, from the purchaser, loan payments on the debt over time from T1 through T3. Financial markets price the capital asset for purchase at time T1 and later for sale at time T4. Debt makes a financial process operate.

However, the traditional economic school, Neo-Classical Synthesis School of Economics, thought there was no difference between the behavior of commodity markets and of financial markets. For a commodity market (commodities of products/services) the basic model is the supply-demand curve of "equilibrium pricing" in a commodity market, as shown in Figure 3.

When the price of a commodity is charted as the quantity of the supply of the product (dotted line), then the price will decrease in an economy as the supply increases. Because of business competition, more goods flooding a market will force prices down. Also if the demand for a product (solid line) increases, then the price will increase (as more consumers buy a limited amount of product). The optimal pricing of a product (commodity) in an economy will occur when supply equals demand. This is the equilibrium price, as supply and demand meet in quantity. If a market behaves like this, it is perfect. No control over pricing is necessary, as a "supply-demand equilibrium" in the market sets the optimal price. (One notes that there is no time-dimension in this graph, which assumes that the equilibrium of pricing was quickly attained in a market and remained stable.) Some economists, such as Allen Greenspan, assumed that financial markets behave the exactly same way as 'perfectly' as a commodity market -- all reaching a respective priceequilibrium. Yet in reality, in economic history, financial markets have repeatedly moved away from equilibrium into price disequilibrium, into financial bubbles. Greenspan ignored history and assumed that financial markets should be 'perfect' (price equilibrium) - whether or not they really were. He did this in 1999 as Chair of the Federal Reserve System, arguing that Congress should not pass a law to regulate the then new financial innovation of 'derivatives' market. Yet only seven years later, the mortgage derivatives market collapsed in a financial bubble, which froze Wall Street banking.

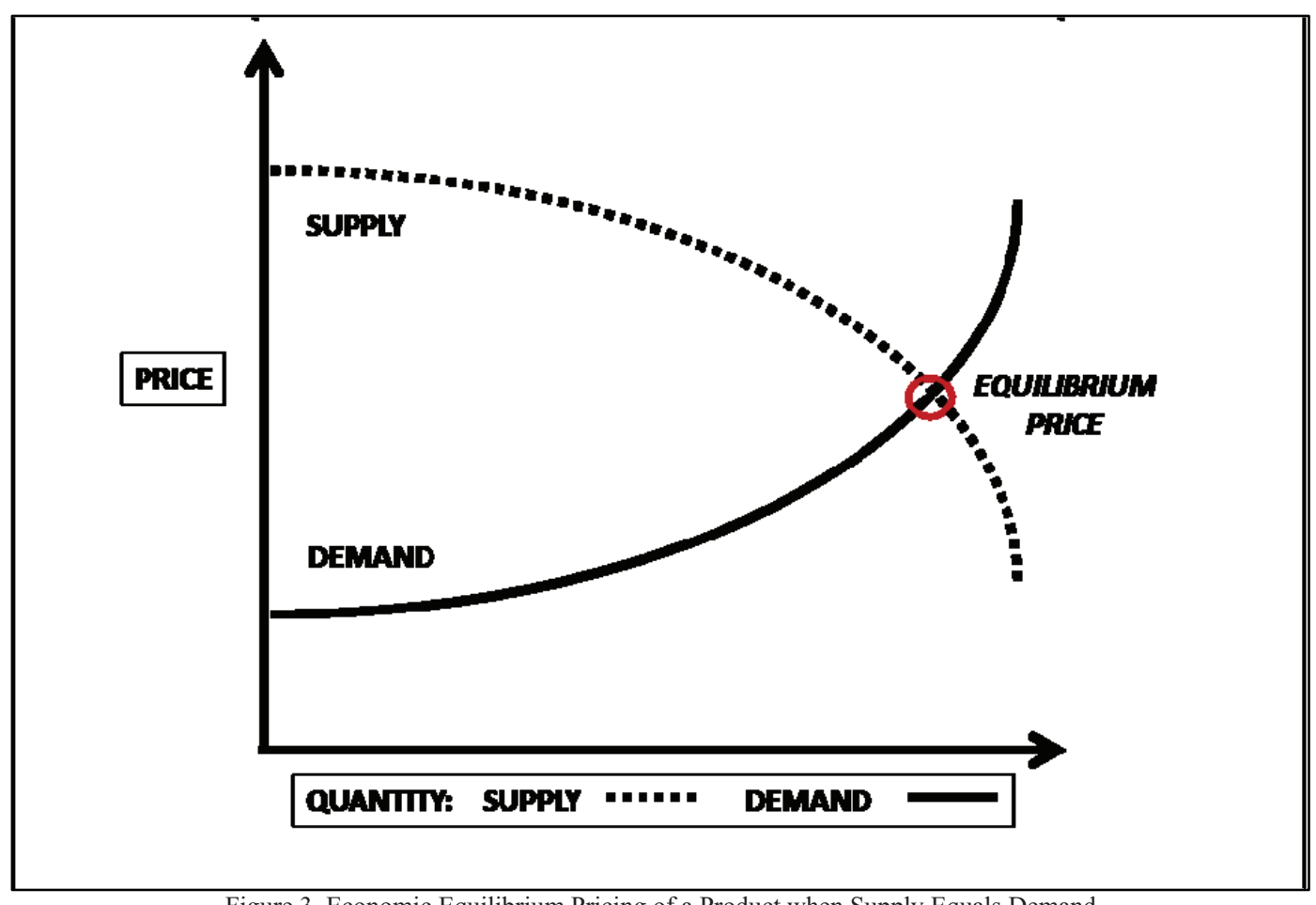

Figure 3. Economic Equilibrium Pricing of a Product when Supply Equals Demand 


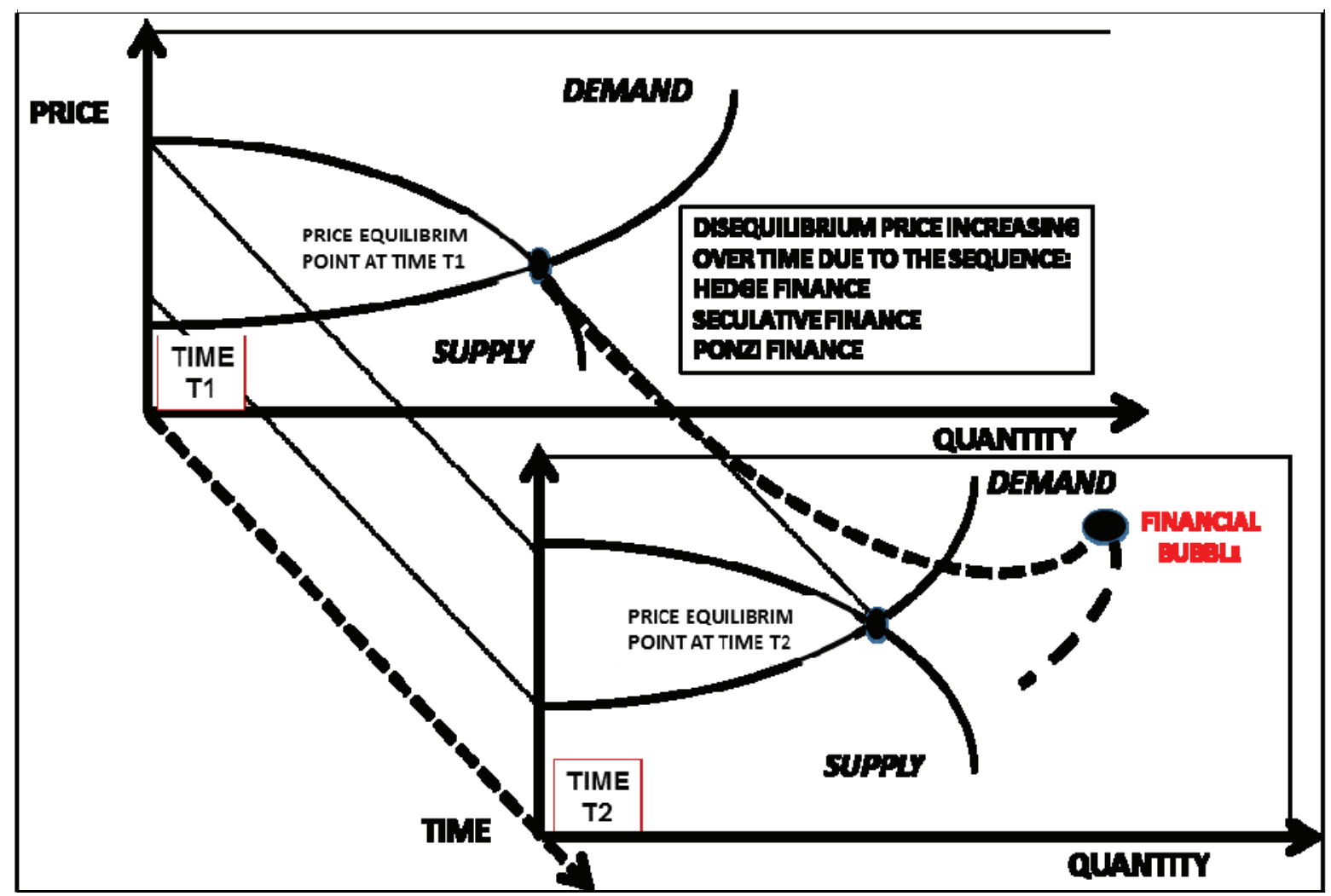

Figure 4. Three-Dimensional (Price, Quantity, Time) Supply-Demand-Price-Disequilibrium Chart - Over Time

Indeed, in 1999, it was this theory of price-equilibrium in financial markets (financial markets were always perfect), which was argued to justify the deregulation of banking in the U.S. Then Glass-Steagle Act was repealed, which had separated investment and commercial banking And this allowed the creation of integrated banks - which proved "toobig-to- fail" and then needed the huge bailing out by the Federal Government in 2008 [6]. The "too-large banks" created a major economic risk in the whole financial system, and they had then to be bailed out by Greenspan's successor, Ben Bernanke.

Thus real financial markets operate very differently from commodity markets, due to the 'leverage' involved in purchasing a capital asset. As shown in Figure 4, the author [4] had indicated the impact of leverage in a price disequilibrium model-by modifying the 2-dimensional price-equilibrium- chart, with the addition of a 3 rd-dimension of time.

This graph shows a supply-demand curve at two different times, T1 and later T2. In the time-dimension, one can see how a "price-disequilibrium" situation can arise over time, as a "financial bubble". It is "excessive leverage" in the financing of a financial market which allows a financial bubble to occur. If no speculation occurs in an asset market (financial market) then the equilibrium prices at T1 and T2 could be the same. But if speculation in the future-price at time T2 occurs in a financial market, a price bubble can begin. Fueled by "leveraged speculation" in the future price of an asset, a "disequilibrium pricing" of the asset growsincreases and increases until the financial bubble bursts.

Then the banks which funded the "leveraged speculation" hold assets greatly decreased in value (from the bursting of the bubble); and this places these banks at risk of "insolvency". When depositors perceive a bank has put it-self at risk, through funding too much speculation, depositors run to take their money out of the bank-a bank panic. Bank panics close down risky banks, and freeze available credit. When too much credit is frozen in an economy, businesses have no access to operating funds, lay off workers or close doors. Financial bubbles have led to bank panics, which created credit freezes, which have led to business failures and unemployment - triggering an economic recession/ depression.

\section{FINANCIAL INNOVATIONS AND BANK PANICS}

Late in the twentieth century and early in the twenty-first century, many new financial products were innovated (facilitated by IC technology). These included: junk bonds, sub-prime mortgages, securitized derivatives, and credit default swaps. However, each of these financial innovations had direct connections to financial crises in that same period in the history of 'Wall Street' and the U.S. economy. The financial innovations were not 'safe' technologies for the U.S. and international financial system. 
We next review these innovations as to their 'technology safety'. In economic terms, the technology safety of an economic transaction lies in its 'public good'. Did these innovative financial products yield a public good or only a private good?

\section{A. Financial Innovation -- Wall Street Junk Bonds}

Junk bonds were corporate bonds issued without corporate collateral; and there was no capital-asset-value backing the bond when issued. The 'leveraged buy-out' junk bonds were highly risky in that if the bond issuer failed; there was no underlying asset to seize. Why were they issued and sold? The issuer could use money the bonds raised to buy companies which did have assets; and these purchases were called 'leveraged buy-outs'. In the 1980s, the junk bond innovation of Wall Street financed the leveraged buy-outs of ongoing businesses. But they also loaded the 'bought-out' businesses with heavy debt. This 'buy-out debt' burdened the companies, reducing the productivity and competitiveness of a 'captive' business (and thereby the competitiveness of the U.S. economy). The junk-bond financial innovation then had Wall Street investment banks moving away from the public good of assisting economic growth in the U.S. economy and instead to stifling growth. Wall Street facilitated investment not for corporate 'productivity' but for corporate 'control'.

Milken focused Drexel on selling and trading bonds without underlying assets, 'junk bonds'. Junk bonds had existed for a long time, as bonds without adequate evidence that the corporation which issued the bond could fulfill its financial contract. What Michael Milken did was to realize that there could be a new market for a new kind of junk bond - a bond without past-value but perhaps future-value. The junk bonds were issued to buy-out existing companies. And for this junk bond market there were new sellers (buy-out artists and hedge-funds) and new buyers (savings \& loan banks, insurance companies, and pension funds). Figure 5 shows the systems model of the scheme, as depicted in [1].

In this disequilibrium model of Drexel's junk bond market, the investment bank of Drexel Burnham led in formulating junk bond offerings for corporate raiders. The Savings \& Loan Bank industry (recently deregulated) eagerly bought the junk bonds because of their high interest rates. Other financial institutions, such as insurance companies, also bought the junk bonds. When the junk bond market collapsed, many of the S\&L banks went bankrupt, as their junk bonds became worthless. From 1986 to 1995, one third of the S\&L banks went bankrupt. S\&L banks were chartered to fund home mortgages in the United States, restricted to mortgages with homes as collateral. In 1980 and 1982, the U.S. Congress deregulated the S\&L industry, allowing these banks to invest in anything and many invested in Milken's junk bonds. When Milken went to jail, and the junk bond

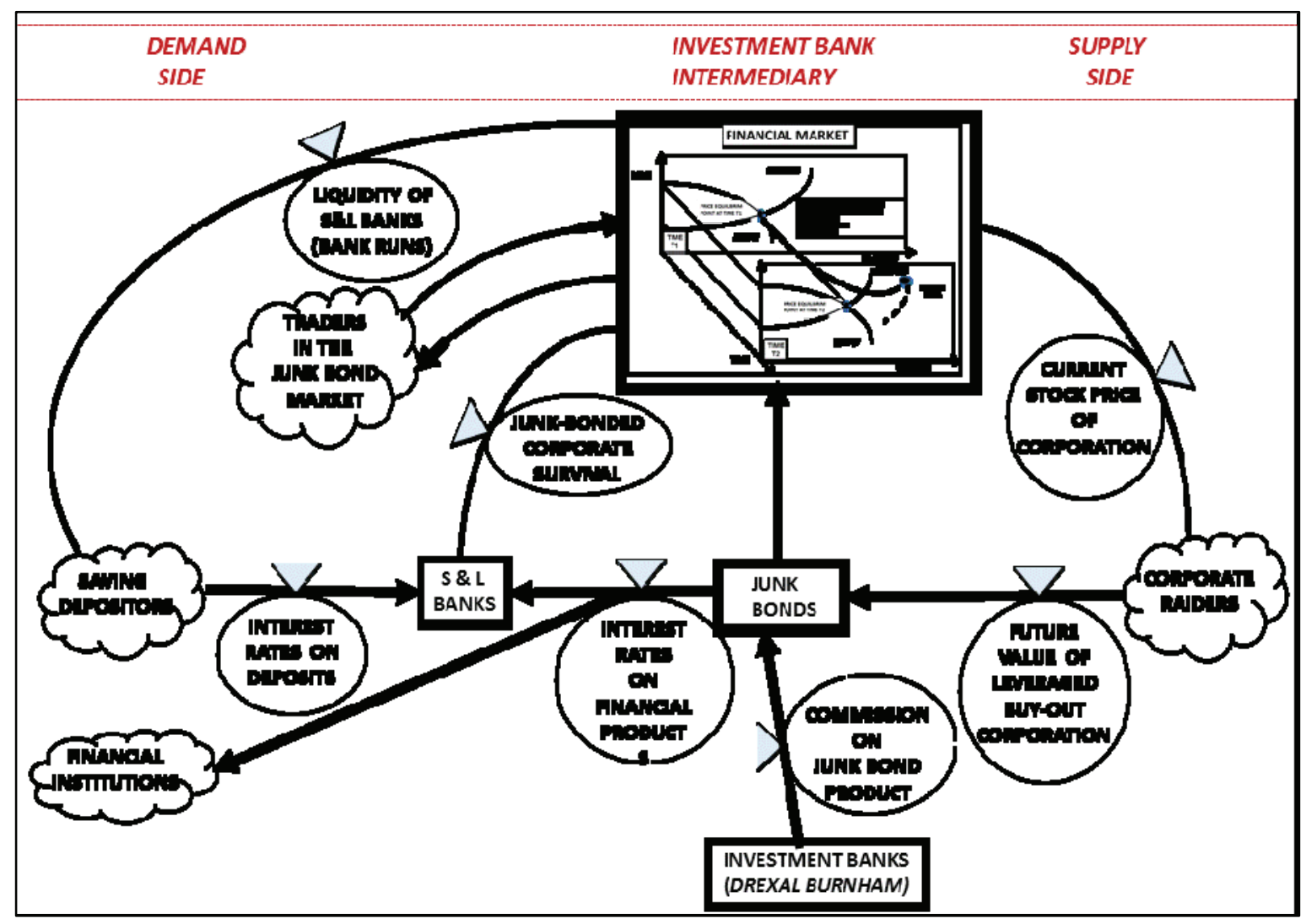

Figure 5. Disequilibrium Systems Model of Corporate Leveraged Buy-Outs 
imploded. The S\&Ls holding junk bonds went insolvent. The U.S. regulatory agencies closed 1043 out of 3234 S\&Ls.

The sellers who issued Milken's junk bonds were 'corporate raiders', people who bought corporate control by buying a corporation's stock, using junk bond financing. With 'junk bond' funding in the 1980s, over a quarter of American corporations were so 'traded' - taken over. The captured corporation had to pay off the junk debt used to capture the corporation; and often could make no investments for the future (such as R\&D and new products). Later (and hopefully) after the captured corporation paid off some of the debt and achieved profits again, the corporation could be taken public again, reaping enormous profits on the investment by the raiders - providing an infinite rate of profit to the raider-trader because they borrowed the money and never held liability for the debt. Some of the stock sales proceeds might be used to pay down some of the debt; but proceeds first went to enrich the corporate raider. Wall Street investment banking went from helping corporations to begin and grow to 'flipping' corporations - a private good with a questionable public good.

\section{B. Financial Innovations - Securitization, Derivatives, and Credit Default Swaps}

Derivatives and Credit Default Swaps were the two financial innovations which brought down Wall Street in 2007-08. The 'sub-prime mortgage' triggered the collapse of the derivative market, which then created the crisis. But the sub-prime mortgage was not a financial innovation, but only a failure of 'quality' in mortgage processing. Prime mortgages enabled people to buy houses by extended the loan period to 15 or 20 or 30 years; and sub-prime mortgages just lowered standards on housing loans to buyers, unqualified in income to pay the loans. The sub-prime mortgages bankrupted Fannie Mae and Freddie Mac but no other financial institutions.

It was the derivatives and credit swaps which created the crisis and bankrupted the other financial institutions. Grechen Morgenson wrote: "Although America's housing collapse is often cited as having caused the crisis, the system was vulnerable because of intricate financial contracts known as credit derivatives, which insure debt holders against default. They are fashioned privately and beyond the ken of regulators - sometimes even beyond the understanding of executives peddling them. Originally intended to diminish risk and spread prosperity, these inventions instead magnified the impact of bad mortgages like the ones that felled Bear Stearns and Lehman and ... threatened the entire economy." [6]

The crisis was due to the securitization of mortgages into mortgage-based derivatives, or as they were called 'collateralized debt objects (CDOs), and these were insured with 'credit default swap' (CDS) contracts. Together the CDOs and CDSs brought down the U.S. financial system; and the crisis ran from 2005 through 2008, in a sequence of events:

2005. Collapse of the U.S. housing bubble.

2006. Collapse of the Mortgage-Based Derivatives Market. (Due to the derivatives using sub-prime mortgages, CDOs.)

June 2007. Collapse of Hedge Funds in Bear Stearns. (Due to formulation of mortgage derivatives, CDOs.)

March 2008. Collapse of Bear Sterns Investment Bank and sale to Morgan Chase Bank. (Due to holding of CDOs.)

7 September 2008. Collapse of Fannie Mae and Freddy Mac and placement into government conservatorship. (Due to purchase of sub-prime mortgages.)

14 September 2008. Bank of America buys Merrill Lynch, in Merrill Lynch's insolvency from their formulation and holding of securitized mortgage bonds, CDOs.)

15 September 2008. Bankruptcy of Lehman Brothers Investment Bank. (Due to formulation of mortgage derivatives, CDOs.)

15 September 2008. Collapse of AIG insurance firm and rescue by U.S. Government. (Due to selling of credit default swaps, CDW.)

15 September 2008. Reserved Primary Fund breaks the 'buck'. (Bank panic due to loans to Lehman Brothers.)

18 September 2008. U.S. Government Guarantee of MoneyMarket Funds

19 September 2008. U.S. Treasury Department announces $\$ 735$ billion dollar TARP program (and conversion of Goldman Sachs and Morgan Stanley into holding banks).

One can see in the bankruptcies (actual and potential) of the financial institutions that only two failures (Fannie Mae and Freddy Mac) were directly due to purchase of sub-prime mortgages. Although subprime mortgage financial products 'spooked' the securitized derivative market, they did not create the bankruptcies in the other institutions.

As shown in Figure 6, even at the height of mortgage lending in 2006, sub-prime mortgages were only $26 \%$ of mortgages. If one regarded all these as risky, one could have merely reduced overall the value of the CDOs by $26 \%$. But this was not done; instead all CDOs became 'toxic assets'.

Moreover, as seen in Figure 7, until the financial collapse of 2007-08, actual failure of subprime mortgages had only been under $10 \%$ per year. Why would this low default rate destroy the whole CDO market? 


\section{Subprime Mortgage Originations}

\section{FIGURE 6}

In 2006, $\$ 600$ billion of subprime loans were originated, most of which were securitized. That year, subprime lending accounted for $23.5 \%$ of all mortgage originations.

\section{IN BILLIONS OF DOLLARS}

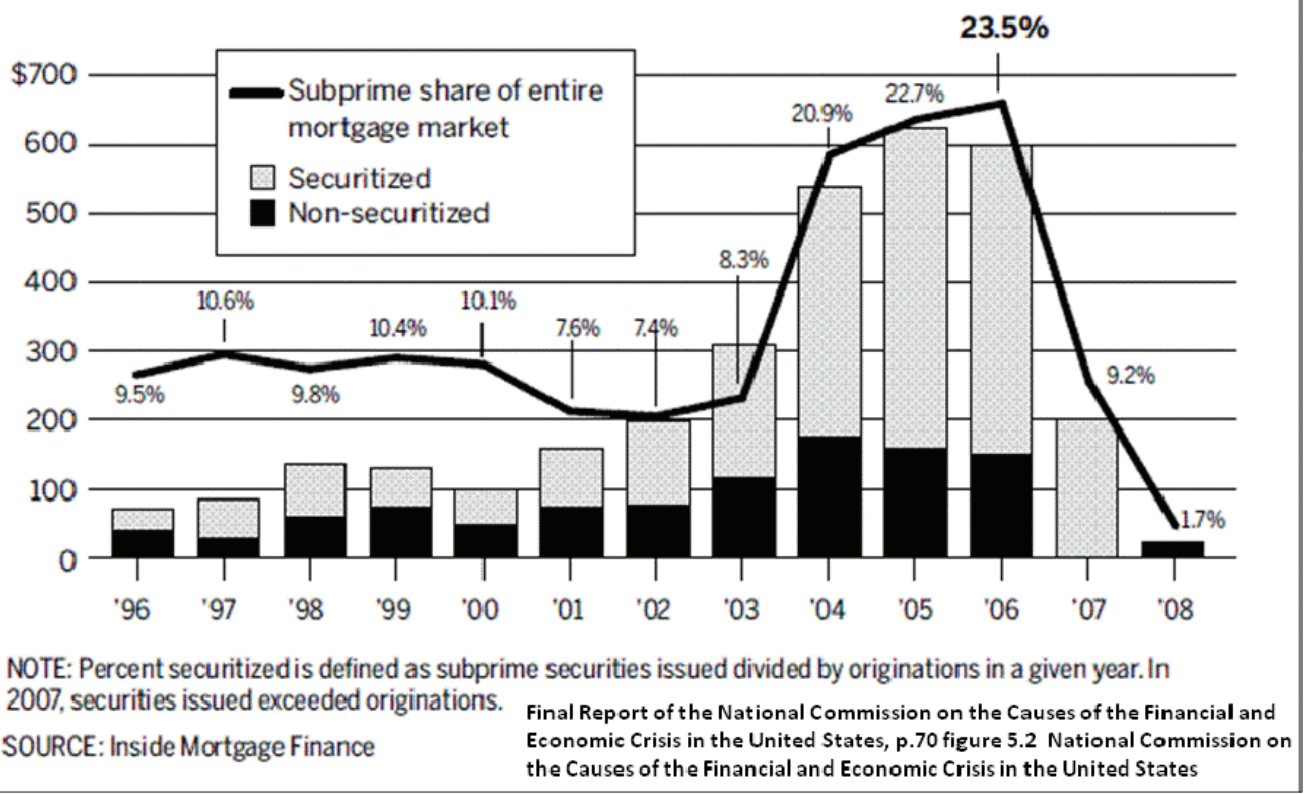

\section{Mortgage Delinquencies by Loan Type FIGURE 7}

Serious delinquencies started earlier and were substantially higher among subprime adjustable-rate loans, compared with other loan types.

IN PERCENT, BY TYPE

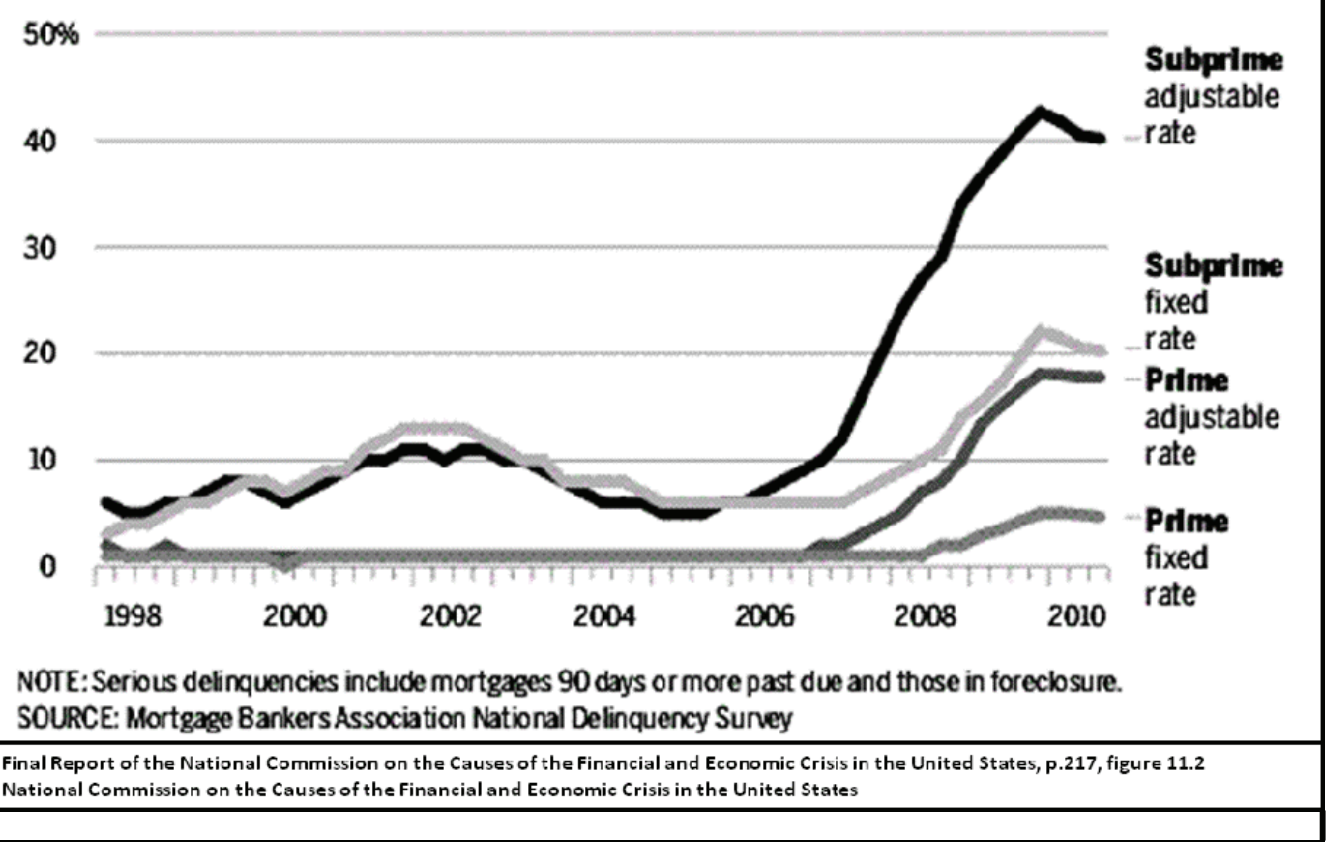


Thus in 2006, the sub-prime mortgages had totaled 650 billion, but with only a $10 \%$ default while composing only $26 \%$ of the mortgage market. Although the 650 billion dollars in the sub-prime mortgage market was a large number, yet the percentage of defaults were low and the percentage of the overall mortgage market was only a quarter. [7] How then did the subprime mortgages trigger a financial meltdown on Wall Street -- which required a $\$ 735$ billion 'bail-out' by the TARP program?

We reviewed how (in the Keynes-Minsky model of financial transactions) financial products traded in financial markets should have two economic values: 'current rent' and 'future liquidity'. Yet the innovation of 'securitization' of mortgages was to violate this standard. The mortgage-bonds had been stripped of their interest 'rent' and so were not sellable again (no future liquidity). The mortgage bonds (stripped of an interest stream) became 'toxic assets.' The derivatives (interest stream) had no underlying collateral value, devoid of their mortgages. The derivatives were not re-sellable without collateral and also became 'toxic assets'. Neither the 'interest-stripped-mortgages' and their 'interest derivatives' had future liquidity! Inadvertently (but by design), the derivatives turned out to be 'toxic assets' - not resellable and without market value.

So the 'derivatives' and 'swaps' were not really 'capital assets'. A financial market built upon products that are 'notreally-capital-assets' was a market doomed to failure -- when holders of these product realized their future worthlessness. It was the holding of the securitized mortgage bonds (toxic assets) which broke Wall Street banks - Bear Sterns and Merrill Lynch and Lehman Brothers. Figure 8 shows a systems-analysis of the securitization scheme for Wall Street financial products of securitized-mortgage derivatives, then called CDO 'collateralized debt-objects'. [4]

The Wall Street investment banks included Bear Sterns, Merrill Lynch, and Lehman Brothers, and all became insolvent (bankrupt) from issuing too many (1) securitized mortgage derivatives (CDOs). But (2) the banks did not purchase the mortgages making up the bonds, only borrowed short-term to fund long-term mortgages. This dependence on the short-term 'repo market' meant that when banks refused to turn-over the short-term loans, the Wall Street banks were suddenly in jeopardy, bankrupt.

This jeopardy occurred when the derivative (3) market price collapsed and then all the (4) mortgage bonds held by the Wall Street banks became unsellable, toxic assets. At this time, the share prices of Bear Sterns, Merrill Lynch, and Lehman Brothers collapsed and other financial houses stopped trading with them - bank runs.

In securitizing mortgage debt, Wall Street had not invented not a 'suitable financial, real capital-asset product'. The derivatives and interest-stripped mortgage bonds were no longer valuable, not liquid capital assets.

The CDO became a 'rent' (interest payment) without collateral; while the securitized (interest-stripped) mortgage bond became a 'toxic asset' without future liquidity.

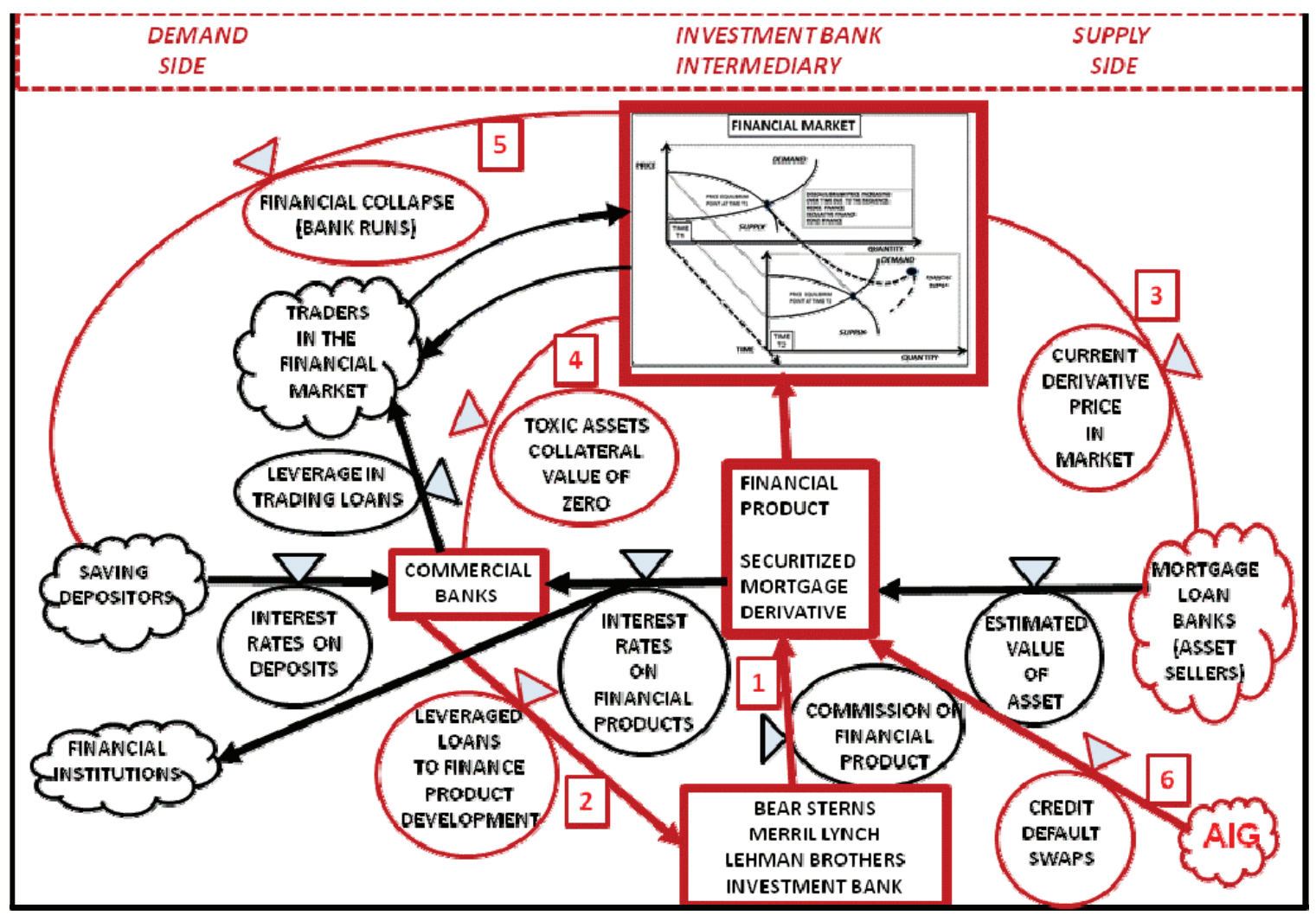

Figure 8. Disequilibrium Systems Model of Investment Bank Process 


\section{September 2008 -- The Securitization Crisis}

Securitization as a financial innovation was not an inherently safe financial technology but an inherently dangerous and fraudulent financial product. The extent of this fraud went through the banking network of Wall Street and was even sold internationally. Then head of the New York Federal Reserve Bank, Timothy Geithner, later summarized that time: "The fall of Lehman was a symptom of the unsustainable leverage and 'runnable' short-term financing throughout the system that made the broader crisis inevitable." [5]

It was not the size of Bear Sterns that mattered in its crisis but its dependence on short-term funding (tri-party repo market) and on securitization. Geithner wrote: "Bear was not that big - only the seventeenth largest U.S. financial institution at the time - but it was completely enmeshed in the fabric of the system. It had nearly four hundred subsidiaries. It had trading positions with five thousand counterparties around the world. And it had borrowed about \$ 80 billion in the tri-party repo market, presenting greater risks of runs on money markets and investment banks . . . About a third of Bear's repo collateral was in the form of mortgage securities." [5]

A 'repo' financial contract is an agreement to sell something at an agreed price and then repurchase at within a given time period; and there is interest on the sell-and-buyback purchase for the term of the agreement. A repro contract is a basic form in which banks to lend to each other for a short term (on the basis of financial assets of the borrowing bank, as collateral for the repo loan). A tri-party repo contract uses a third bank as custodian for the transaction, to administer the loan. In the United States, JP Morgan Chase and Bank of New York Mellon have been key institutions in administering tri-party repo loans between Wall Street banks. At the time of the fiscal crisis in 2007-08, repo market was key component for short-term bank liquidity.

In the March 2008 when Bear Sterns collapsed, they had been using short-term borrowing to purchase mortgage bonds - and which suddenly ended for Bear Sterns. Timothy Geithner wrote: "The most flammable parts of the system were the institutions reliant on tri-party repo and other shortterm financing markets, ... Bear Stearns had to ratchet up its reliance on tri-party repo in 2007, after creditors stopped rolling over its commercial paper; now a sizable chunk of the collateral behind its repo book was in illiquid assets (the toxic, securitized bonds), and it wasn't clear how long its lenders would accept them. . . (Bear Sterns) was the smallest and most leveraged of the five major investment banks, with $\$ 400$ billion in assets and \$ 33 in borrowing for every dollar of capital. It was seen as Wall Street's weakest link, badly managed, disproportionately exposed to mortgages." [5].

In September 2008, six months after Bear Sterns' failure, the investment banks next in line for failure were Merrill Lynch and Lehman Brothers. Timothy Geithner wrote: “ . . . the investment bank Merrill Lynch announced \$ 7.9 billion in mortgage-related losses, the largest write-down in Wall Street history. That was almost twice as large a write-down as Merrill had predicted three weeks earlier, leaving the impression that losses were exploding and more unpleasant surprises lay ahead. Merrill CEO Stan O’Neal was forced out, although he did receive a $\$ 161.5$ million severance to ease the blow. The bulk of Merrill's losses came from 'collateralized debt obligations,' piles of mortgage-backed securities, where the income streams had been sliced up and repackaged into smaller streams known as "tranches." Merrill was a leading manufacturer of CDOs, and it had made billions selling them to investors around the world. [5]

The bankruptcy of Lehman Brothers unleashed the Wall Street bank panic at full scale. This short-term financing of mortgage derivatives had been pervasive. Even the large Wall Street commercial banks had woven this fraudulent net of derivatives, which would trap them all, in their 'financial dance'. Timothy Geither wrote: "The mortgage contagion soon infected one of the world's biggest banks, one of the New York Fed's banks. On November 4, Citigroup broke Merrill's new record, warning that it might take as much as \$ 11 billion in write-downs, seven times what it had projected on an earnings call three weeks earlier. Citi also revealed it had $\$ 55$ billion worth of subprime exposure, four times what it had said on that mid-October call. Citi's last piece of news was that Chuck Prince, the CEO who had said banks needed to keep dancing while the music kept playing, was out of a job. Clearly, the music had stopped. . . . message was that Citi was out of control." [5]

\section{Financial Innovation - AIG and Credit Default Swaps}

As indicated in the earlier Figure 6, the short-term funded and rent-stripped mortgage bonds underlying the derivatives (CDO) had collapsed Wall Street. Moreover, the financial crisis was compounded and deepened by [6] the portending collapse of the insurance company AIG. AIG had issued billions of dollars ( $\$ 135$ billion) of insurance contracts, as credit default swaps (CDS) -- to the Wall Street banks, on issuing their CDOs. What are credit default swaps? What was a reputable and regulated insurance company, AIG, doing issuing such financial contracts -- and at such an extraordinary large amount (\$135 billion dollars)?

A credit default swap (CDS) was a financial contract for the issuer (e.g. AIG) to pay the recipient (e.g. Lehman Brothers) the value of a debt (e.g. CDO) if the debt defaults. Since the securitized derivatives CDOs carried not collateral, the issuers of CDOs bought 'insurance contracts' on a CDO to pay off the debt if the mortgages in the CDO default. Credit Default Swaps (CDS) were treated as a kind of insurance on a financial loan. But, in fact, they were not really 'insurance' for two reasons. First, there was not actuarial basis for pricing the insurance. Second this faux insurance was issued to anyone, including people who did not own the asset being insured. Yet AIG issued billions of dollars in their 'faux' insurance contracts of CDSs.

The AIG issuing CDS contracts occurred when a J. P. Morgan team needed a way to convince people to buy 


\section{Proceedings of PICMET '16: Technology Management for Social Innovation}

derivatives (since they had no collateral if the bonds of the derivatives failed). Insurance would persuade Morgan's customers that mortgage derivatives were 'safe'. Gretchen Morgenson wrote: "Under the terms of the insurance derivatives that the AIGFP London unit underwrote, customers paid a premium to insure their debt for a period of time, usually four or five years . . . Many European banks, for instance, paid AIG. to insure bonds that they held in their portfolios. Because the underlying debt securities - mostly corporate issues and a smattering of mortgage securities carried blue-chip ratings, AIG Financial Products was happy to book income in exchange for providing insurance. After all, Mr. Cassano and his colleagues apparently assumed, they would never have to pay any claims." [6]

This was the key assumption. If AIGFP could earn one million a year for five years for insuring a \$100 million CDO derivative, than Cassano's AIG team would earn a bonus of $30 \%$ of five million ( 1.5 million), which is $\$ 300,000$ per year. Good for Cassono's team! But for those five years, AIG would be on the hook for $\$ 100$ million, if mortgages in the CDO defaulted during that time. Not so good for AIG!

Gretchen Morgenson wrote: "Since A.I.G. itself was a highly rated company, it did not have to post collateral on the insurance it wrote. That made the contracts all the more profitable. These insurance products were known as "credit default swaps," or C.D.S.'s in Wall Street argot. The London unit used them to turn itself into a cash register. The unit's revenue rose to $\$ 3.26$ billion in 2005 from $\$ 737$ million in 1999. Operating income at the unit also grew, rising to 17.5 percent of A.I.G.'s overall operating income in 2005, compared with 4.2 percent in 1999 . Profit margins on the business were enormous. In 2002, operating income was 44 percent of revenue; in 2005, it reached 83 percent. $\mathrm{Mr}$. Cassano and his colleagues minted tidy fortunes during these high-cotton years. Since 2001, compensation at the small unit ranged from $\$ 423$ million to $\$ 616$ million each year, according to corporate filings. That meant that on average each person in the unit made more than $\$ 1$ million a year. In fact, compensation expenses took a large percentage of the unit's revenue. In lean years it was 33 percent; in fatter ones 46 percent. Over all, A.I.G. Financial Products paid its employees $\$ 3.56$ billion during the last seven years."[6]

And in 2008, it did turn out to be 'not so good' for AIG. In 2009, Richard Tetelbarum and Hugh Son wrote: "New York-based AIG's gargantuan gambles have become synonymous with the near collapse of the global financial system and the ensuing worldwide economic slump. . . . It was AIG's gambits on mortgage-related debt that brought the world's largest insurance company to the edge of bankruptcy last September (2008) . . . . The Fed and the Treasury have paid out or guaranteed a total of $\$ 182.5$ billion for AIG, more than four times the $\$ 45$ billion Bank of America Corp. and Citigroup Inc. each got through the Treasury's Troubled Asset Relief Program, or TARP. The U.S. has committed as much as $\$ 70$ billion of TARP money to AIG. AIG, more than any other institution, has thrown a spotlight on the tangled world of derivatives -- securities whose value is derived from underlying stocks, bonds, currencies or commodities -- and especially on credit-default swaps (CDS). [8]

This is how the TARP program rescued Wall Street and spared the US a depression from the financial innovations of Wall Street. Richard Tetelbarum and Hugh Son wrote: "The government rescued AIG to avert "systemic failure," Federal Reserve Chairman Ben S. Bernanke said at the time. If AIG had collapsed, a dozen other big financial companies that were counterparties in its derivative trades and insurance contracts might have gone down along with it, Bernanke told Congress in March. By the end of 2008, more than $\$ 60$ billion was paid to AIG counterparties that had bought CDSs from AIG. . . . Paris-based Societe Generale got $\$ 16.5$ billion in collateral and other payments from late 2007 through 2008; New York-based Goldman Sachs Group Inc. received \$14 billion; Frankfurt-based Deutsche Bank AG, \$8.5 billion; and Merrill Lynch \& Co., $\$ 6.2$ billion. The payments were triggered by the credit-rating downgrades of AIG and declines in the market value of the assets protected by the swaps. The most volatile of those assets were collateralizeddebt obligations, or CDOs, which are agglomerations of subprime mortgages and other debt that are divided up and sliced into tranches, each of which has a different risk and income stream." [8]

\section{TECHNOLOGY AND SAFETY - FINANCIAL SYSTEM INNOVATION}

What one discovers in examining the financial technology of crises is that the failures of the financial system have resulted from financial innovations. These provided some private good, temporarily (a financial bubble), but did not always have public good, when the a bubble collapsed. Economists have used the terms of private and public good to distinguish between the benefit of economic transactions to individuals and to the society of the individuals. A 'public good' indicates a product/service produced in a society which is shared by all members of society. This is in contrast to the term 'private good' in which the product/service is consumed only by a particular member of society.

Martin Wolf wrote: "Public goods are the building blocks of civilization. Economic stability is itself a public good. So are security, science, a clean environment, trust, honest administration, and free speech. The list could be far longer. This matters, because it is hard to secure adequate supply. The more global the public goods, the more difficult it is. Ironically, the better we have become at supplying private goods and so the richer we are, the more complex the public goods we need. Humanity's efforts to meet that challenge could prove to be the defining story of the century. . . (now) a central element of debate is how to avoid extreme financial instability. Such instability is a public bad. Avoiding it is a public good." [9]

And historically it turns out that avoiding a financial collapse is not easy. Martin Wolf wrote: "Economists have tended to assume that the market economy is inherently 
stable. If so, stability is supplied automatically. Unfortunately, this is not so. A free-market economy can expand credit without limit, at zero cost. Since money supply is simply the liability counterpart of private credit decisions, instability is baked in the economic cake. For this reason, economic stability is a public good we find quite hard to supply. The consequences of the repeated failure to do so can also be dire. Even the late Milton Friedman believed that government intervention, via the central bank, was needed to prevent long chains of banking collapses." [9] The technology in financial products should be regulated to ensure a public good.

\section{CONCLUSION}

When financial technologies are unregulated, then product innovation can facilitate a form of 'gambling' in the banking system, casino banking'. The technology may entice financial system away from its traditional public good in financing economic growth. In 2009, the U.S. Congress had established an inquiry to investigate the Global Financial Crisis of 2008; and Phil Angelides was appointed Chairman of the U.S. Congress Financial Crisis Inquiry Commission. In 2011, Angelides talked about his experience: "I came into my position as chairman of the commission with what I thought was a reasonable understanding of the American financial system, and I had this quaint notion that it was a system designed to allocate capital to the economy for the purposes of creating jobs in enterprise and long-term sustained wealth for our society. I must tell you that over the course of the last year and half, I, along with my fellow commissioners, undertook a journey of revelation. As we did our investigation, we were surprised, we were shocked, we were fascinated and often appalled at what we found. I often felt as if I had entered my local community bank, had opened a door that I wasn't suppose to open, and when I opened it, I saw a casino floor as big as New York, New York. And, I may add, that unlike Claude Raines in Casablanca, I was truly shocked at the level of gambling that was going on in Wall Street." [10]

In the twenty-first century, 'Wall Street' investment banking in the U.S. moved away from its traditional economic role toward 'casino banking' - toward innovating financial gambling. Casino banking gambles high-risk financial products of questionable quality, little public good, and prone to market bubbles. We have examined the historical cases of financial innovation which converted Wall Street from investing in the public good of economic growth into casino banking. In Figure 9, we show again the systems disequilibrium model of the role of financial products in creating financial markets -- but simplified to focus upon the destabilizing connections of casino banking. [3]

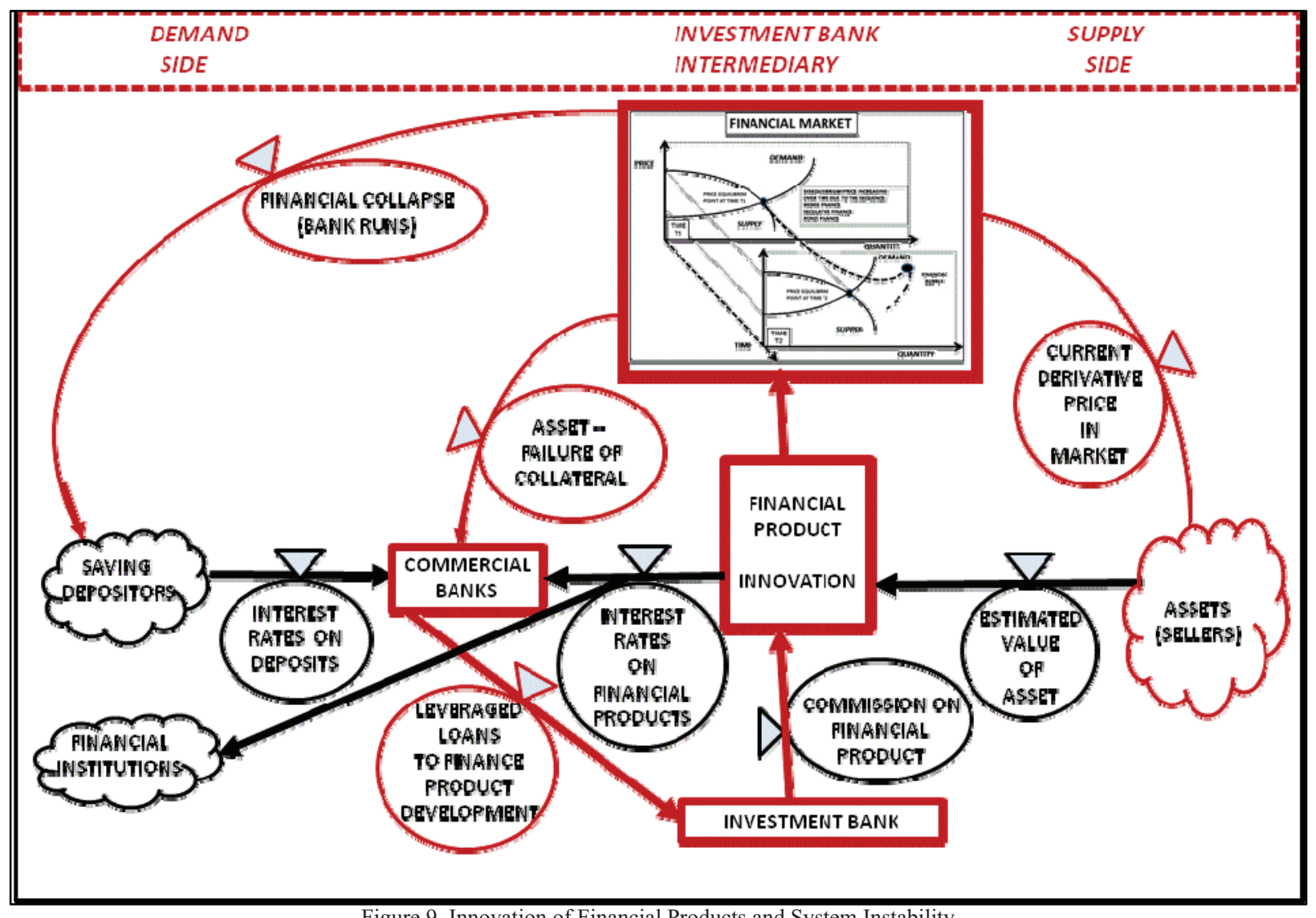

Figure 9. Innovation of Financial Products and System Instability 


\section{Proceedings of PICMET '16: Technology Management for Social Innovation}

As Figure 9 again emphasizes, it is type of financial product issued by an investment bank which creates a financial market in which he financial products are traded. The collapse of the market in a financial bubble, renders the products valueless and buyers of the products may become insolvent, as well as the commercial banks which lent money to leverage the financing of the production of the products. Thus the stability of the financial system depends the financial product in: (1) liquidity of the product, (2) leverage in producing the product, and (3) liquidity of the product as bank collateral. Regulation of the types of financial product which a government allows to be sold in financial markets is the safeguard against financial products which destabilize a financial system - products which have little public good.

In the case of the financial product of the junk bond (forfinancing-leveraged-buyouts-of-an-existing-corporation), there is no public good in burdening an ongoing business with debt, it does not need to improve competitiveness and productivity. Such buy-out debt only limits the corporation from investing for a productive future. The U.S. Security Exchange Commission (SEC), which regulates publicallylisted companies, should not allow the transfer of leveragebuyout-debt from the corporate raider onto the captive company's books. It is the transfer of buy-out debt, from the captor onto to the captive, which creates the public 'bad' in leveraged buyouts.

In the case of the financial product of the asset-securitized derivative, there is no public good in financial products which have no future liquidity (are not re-sellable in a financial market). It is the selling of faux-financial products of high risk and no future liquidity which creates instability in the financial system.

In the case of the financial product of a credit-defaultswap, there is no public good in a 'faux insurance', in an insurance which pretends to make a debt safe but cannot payoff when the financial market of the product collapses. All financial markets are subject to periodic collapses because of the nature of speculation and leverage in the dynamics of financial markets, and therefore no insurance scheme for financial products be profitable in the long run, without a predictable actuarial scheme.

Thus in the case of the 2008 crisis, the crash was due to bad products (bonds stripped of interest and could not be resold) -- toxic assets. Also the credit default swaps were bad products because they were sold as insurance -- but were not really insurance products, since they had no real actuarial basis. Reforming the system first requires not allowing fraudulent financial products to be sold in the market, which the Dodd-Frank bill did not address.

\section{REFERENCES}

[1] Betz, Frederick. 2015. "Price-Disequilibrium Model of the International Financial Grid: Innovation, Crisis, and Off-Shore Banking." Business and Management Research Vol. 4, No. 3; 2015. Published by Sciedu Press 43 ISSN 1927-6001 E-ISSN 1927-601X. www.sciedupress.com/bmr

[2] Mcgee, Suzanne. (2010). Chasing Goldman Sachs: How the Masters of the Universe Melted Wall Street Down...And Why They'll Take Us to the Brink Again. Crown Publishing Group.

[3] Minsky, Hyman. (1975). John Maynard Keynes. Columbia University Press (reprinted in 2008 by Mc Graw Hill)

[4] Betz, Frederick. 2014. "Disequilibrium Pricing Theory—Bubbles and Recessions." Theoretical Economics Letters, 2014, 4, Published Online February 2014 (http://www.scirp.org/journal/tel)

[5] Geithner, Timothy F. (2014-05-12). Stress Test: Reflections on Financial Crises. Crown; 1st edit (2014-05-12) (1800) B017WQLQWK

[6] Morgenson, Gretchen. 2008. "Behind Insurers Crisis Blind Eye to a Web of Risk." New York Times. September 27. www.nytimes.com/2008/09/28/business/28melt.html?_r=0\&pagewante $\mathrm{d}=$ print

[7] Betz, Frederick and Tarek Khalil. 2011. "Technology and Financial Innovation", International Journal of Innovation and Technology Management, January. Vol. 08, No. 01.

[8] Teitelbaum, Richard and Hugh Son. 2009. “ Unwinding at AIG Prompts Pasciucco to Ponder Systemic Failure." Bloomberg L.P. July 1. http://www.bloomberg.com/apps/news?pid=newsarchive\&sid= afDX3.N1Kdgw

[9] Wolf, Martin. (2014). The Shifts and the Shocks: What we've learnedand have still to learn - from the financial crisis. Penguin Books Ltd.

[10] Angelides, Phil. 2011. "Justice, Reform, and Rebuilding in the Wake of the Financial Crisis". Levy Economics Institute of Bard College. 20th Annual Hyman P. Minsky Conference on the State of the US and World Economies. April 13-15, 2011, New York City. 